\title{
Design for Vendor Profile Data Management Improvement Solution in Direct Material Procurement PT. X
}

\section{Tanti Octavia and Ong Merryana Pranata}

Industrial Technology Faculty, Industrial Engineering Departement, Petra Christian University, J. Siwalankerto 121-131, Surabaya 60236, East Java, Indonesia

\section{Abstract}

PT. $X$ is a multinational company in Indonesia which is engaged in the consumer goods. This research was conducted in one of department that support the process in PT. $X$ that is direct material (DIM) Procurement department. One of DIM Procurement's role is to manage vendor's document and data profile. The data is used by DIM user for purchase order process, payment process and other various process in PT. X. DIM Procurement expects a more efficient and effective work system, so DIM can manage every process and also to better serve DIM user. The problem identification results show there are four main problems that occurred in the process of vendor

Corresponding Author:

Tanti Octavia

tanti@petra.ac.id

Received: 16 February 2020

Accepted: 5 March 2020

Published: 10 March 2020

Publishing services provided by

Knowledge E

(c) Tanti Octavia and Ong

Merryana Pranata. This article is

distributed under the terms of

the Creative Commons

Attribution License, which

permits unrestricted use and

redistribution provided that the

original author and source are credited.

Selection and Peer-review unde the responsibility of the ICLBI (2018) Conference Committee.

\section{G OPEN ACCESS} profile data management. The main problems such as vendor data review process is not running effectively, the process of delivering information is not effective, the long processing time of update profile data, and the process is not transparent. Root causes analysis is conducted using five whys analysis method and the results show there are 19 root causes that occurred in the process of vendor profile data management. Digitalization is the overall solution that can fix the process of managing vendor profile data. Digitalization will change the initial process of delivering information from using e- mail, now using an online portal system called DIM Vendor Profile Management. DIM Vendor Profile Management system will connect each parties who involved in the process and improve the process to becoming more effective, efficient, and transparent.

Keywords: five whys analysis; root cause analysis; vendor profile management.

\section{Introduction}

PT. $X$ is a multinational company in Indonesia which is engaged in the consumer goods. PT. $X$ has a company structure that consisting of several departments. One of department that support the process of PT. $X$ is DIM Procurement. The role of DIM Procurement is to manage the procurement process of direct material, so the production process can be running smoothly. Managing vendor's document and profile data is one of DIM tasks. Vendor profile data is data legality of vendor such as address, ownership, e-mail address, Bank detail, tax, term of payment, contact number, and etc. Vendor 
profile data is managed and stored in a Vendor database PT. $\mathrm{X}$ called Vendor Master Data Management (VMDM).

Vendor profile data is used for some process such as purchase order, payment, data confirmation, and other process in PT. X. DIM have to ensure that the profile data is available and the current data on system is up to date. The process of managing vendor profile data is related to update the data on system. Profile data from vendor have to be verified first by several parties, before it can be updated on the system. Verification process aims to ensure that the data is valid and safe to use by user.

TABLE 1: Frequency of update process from November 2017 until January 2018.

\begin{tabular}{|l|c|c|c|c|c|}
\hline Process & Nov & Dec & Jan & Total & Average \\
\hline Create & 104 & 39 & 22 & 403 & 135 \\
\hline Change & 139 & 139 & 125 & 165 & 55 \\
\hline Total & 243 & 178 & 147 & 568 & 190 \\
\hline
\end{tabular}

Based on data from November 2017 till January 2018 (Table 1), there are 190 update process per month with total of 162 vendors. The update process itself is divided to create process and change process. Create process is the process of registering new vendor into the system. Meanwhile change process is the process of changing vendor data on system. Create process takes $8 \mathrm{~d}$ to complete, while change process takes $3 \mathrm{~d}$ to complete. Create process is done through six-step process and change data is done through five-step process.

Due to the data obtained, the three-step process time of create data and the two-step process time of change data is known. Total process time of each process that known is given in Figure 1.

Figure 1 shows that the process time of update data is varied and takes up to days. There are 39 out of 256 process that require process time that exceed the overall processing time. The longest process time takes up to $17 \mathrm{~d}$. Even this data only shows the process time of some step process. This data indicates that the process of updating vendor profile data is not fully working properly. In that time, there is a possibility that the data is required by user. Sometimes, user also didn't know if there is a change of vendor profile data. The long process time and non-transparent process can cause unavailability and inaccuracy of data when it's intended to be used by user.

Therefore, an in-depth analysis is needed to find the root cause of vendor profile data management process that is not fully working properly. The analysis is conducted by using Root Cause Analysis method to identify in detail of the root cause that actually 


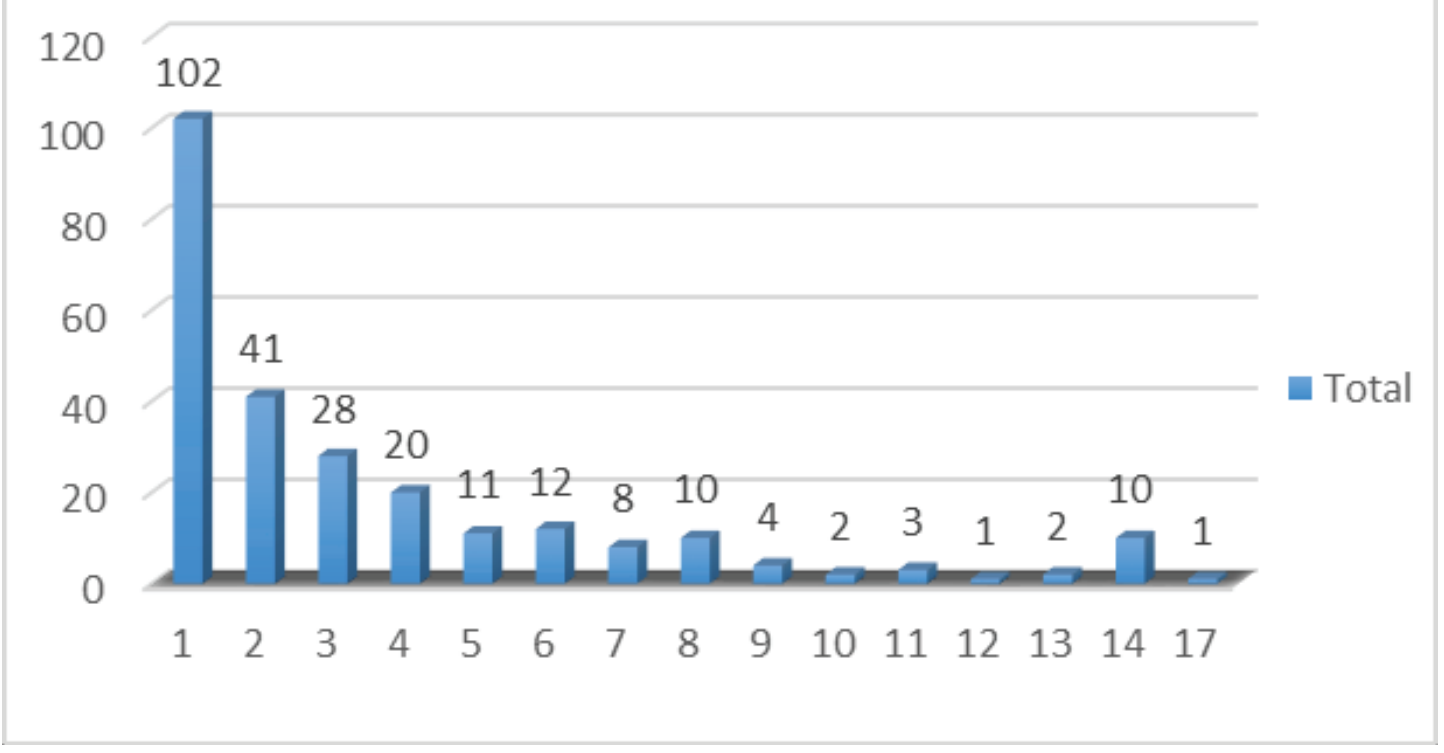

Figure 1: Total completion of updating data processing time

occurs. The root cause will be solved with a proposed solution that will directly meet the DIM's desire to improve the work system to be more efficient and effective.

\subsection{Problem statement}

There are 190 update process on average that occurs every month. Data of update process from November 2017 until January 2018 indicates that there are 39 out of 256 process is requiring process time that exceed the overall process time. In addition, there are various problems that occurs in the process of vendor profile data management. The problems can cause unavailability and inaccuracy of data that used by user. It can obstruct the process that running in PT. X. In order to find out the root cause that occurs in the process of vendor profile data management, a root cause analysis is needed to identify the real cause that actually occurs in the process.

\subsection{Research questions}

The research addressed four questions. First, what are the roots cause identified in the process of vendor profile data management in DIM procurement? Second, how to fix the process of vendor profile data management in DIM procurement? Third, how is the design of the proposed improvement solution for process vendor profile data management in DIM procurement? Fourth, what is the impact of the improvements on the process of vendor profile data management in DIM procurement? 


\subsection{Purpose of the study}

This research aims to identify the root cause of vendor profile data management, determine the proposed improvement solutions, designing the concept and design of the proposed solution, and the last is to know the impact of the improvement solutions that given.

\section{Conceptual models}

Today's companies have variety of technology solutions that can increase the efficiency and transparent their process. Digital transformation is one of innovation that can improve the business process in a company, especially on procurement. This research using digital transformation as the key to improve the process of vendor profile data management. Conceptual models in this research is given in Figure 2.

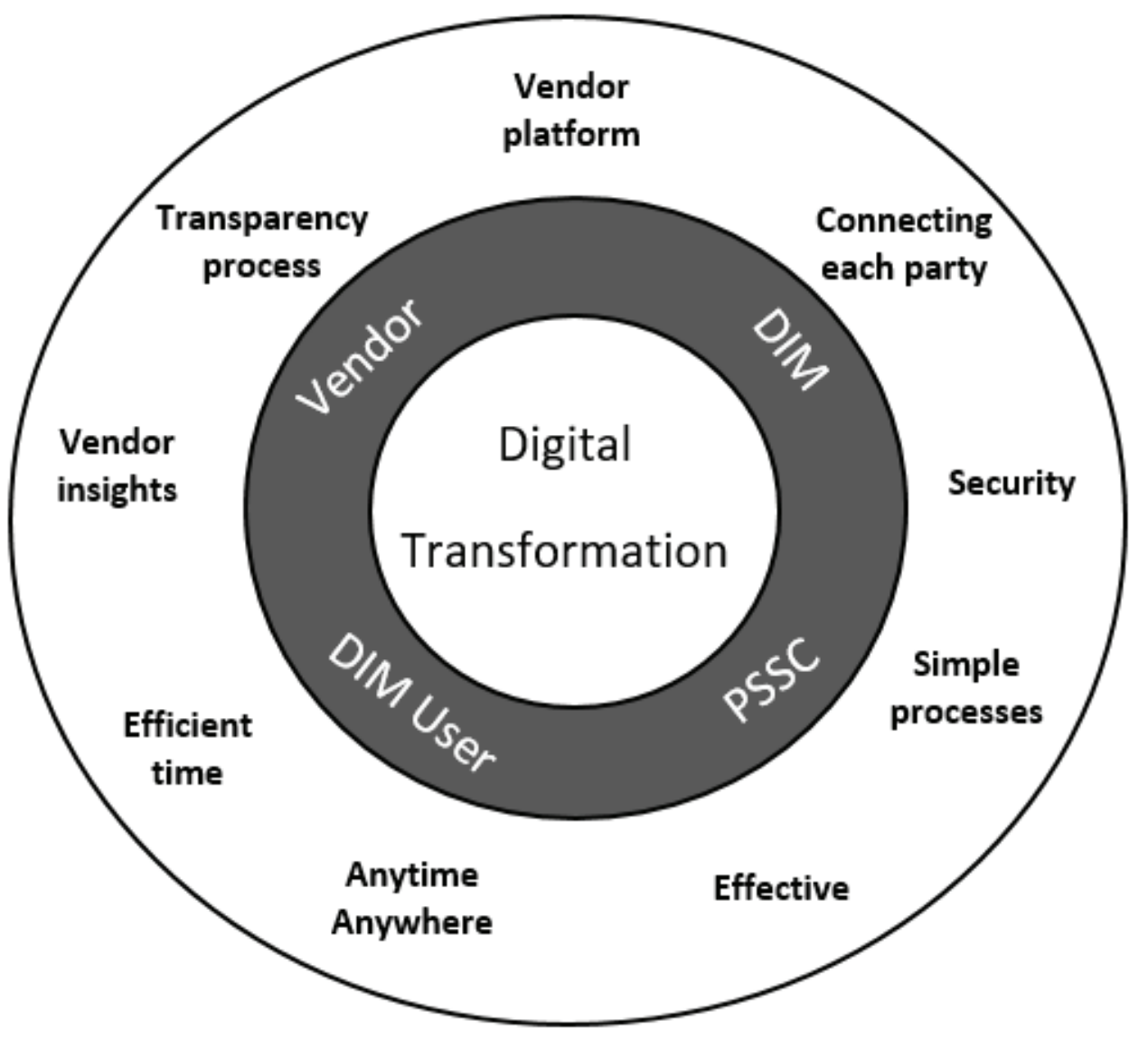

Figure 2: Conceptual models.

In digital transformation, vendor should be taken on a journey through the process of their profilles management. Now, vendor have the roles to manage their profile 
directly on a vendor portal. Each party that involves in the process can also connecting with digital transformation. The information will be more transparent, the process more efficient and effective, and increasing the security of information.

\section{Research methodology}

Industry 4.0 is the fourth industrial revolution in manufacturing and industry. Industry 4.0 is the superposition of the technological development that focuses on the integration of the products and processes [1]. Industry 4.0 using digital technology to enhance operational efficiency, helps a company become more rapid, flexible and responsive to the customer as well as able to provide information in real time [2]. Therefore, Päivi Parviainen et al proposed a starting point for a systematic approach to tackle digital transformation that will help companies analyze the impact of digitalization and the needed steps for their specific environment [3].

Revolution in industry also encourages the onset of revolution for procurement. According to Yukins and Schooner [4], procurement is an activity to obtain goods or services in a transparent, effective and efficient manner in accordance with the needs and desires of its users. Along with the effects of industry 4.0's cutting-edge technologies and data management on strategic, then undertook to encourage development in the areas of procurement called Procurement 4.0. Procurement 4.0 describes the changes in every aspect that lead to digital technology. Procurement 4.0 procurement focused on the six areas as follows [5]:

1. New procurement value proposition

2. Digital category and service procurement

3. Digital supply chain and service procurement

4. Innovative procurement data utilization

5. Digital processes and tools

6. Organization and capabilities

\subsection{Root cause analysis}

Root cause analysis (RCA) is defined as a structured approach which has a primary focus to identify and resolve the problem [6]. Identify the root cause is the key to prevent the 
same problem happening again [7]. RCA helped to produce a recommendation that is effective against the problems, also to prevent the same problems reoccur [8]. Mourtzis et al tried to adopt concepts from the Root Cause Analysis method, which is further enriched with knowledge reuse feature [9].

\subsection{5 why analysis}

5 whys analysis is the simplest method in RCA to analyze the root cause of problem with structured, so the cause and effect relationship underlying a problem can be known [10]. This method was first developed by Sakichi Toyoda and is an important part of the problem solving in Toyota Production System. According to Taiichi Ohno who was a manager of Toyota in the year 1950, troubleshooting requires identification of the cause and not the source. The root cause is hidden behind the source, so by repeating the question "why?" then the true cause will be found. The 5 whys analysis step is shown in Figure 3

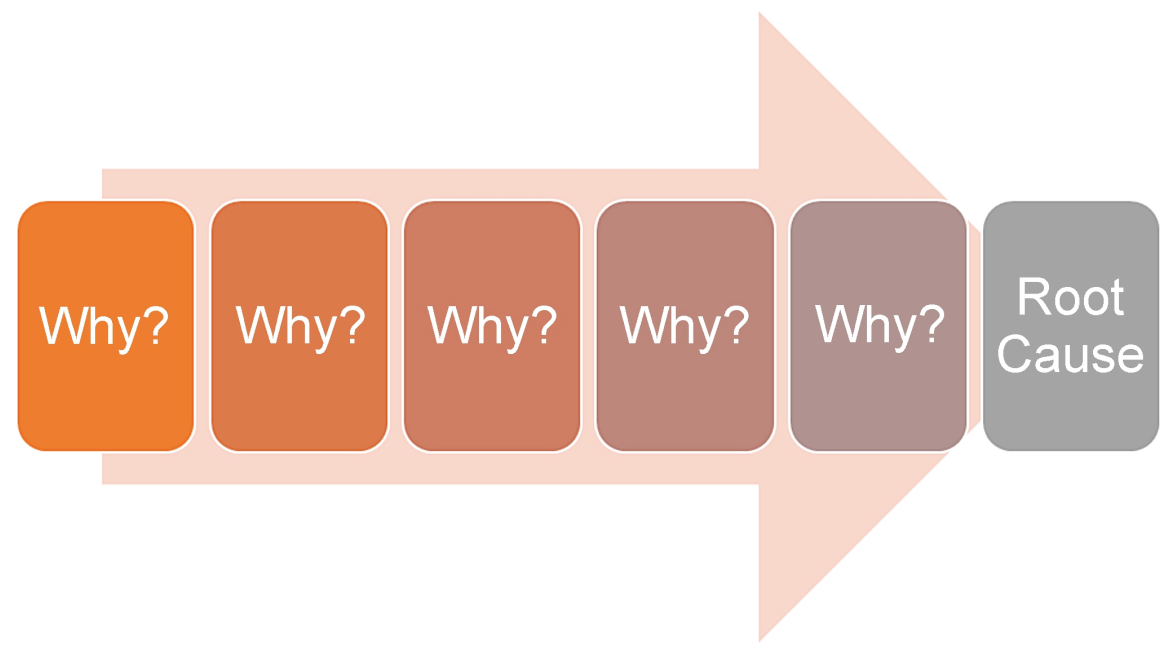

Figure 3: Five Whys Analysis Step Process

Figure 3 shows the method five whys analysis performed repetition of questions why, up to several times to ensure the root cause are known. The questioning does not have to stop at fifth, because it could have been the root of the problem was discovered before or even taken further to higher level. This method helps to find root cause and appropriate solutions using experience of the problems that occur [11]. 


\section{Findings}

\subsection{Vendor profile data management}

Vendor profile data is one of important data that is managed by DIM Procurement and stored in an online database called VMDM. Data on VMDM will automatically synchronized with the data in the SAP system. The user that need all vendor data must download the data from SAP system. In process of update vendor profiles, information from vendor have to be verified before it can be updated on system. Vendor also have to attach the document which support their data profiles. There are several parties that involves in the process of updating data, such as vendor, DIM, Procurement Support Center (PSC), Procurement Shared Serviced Asia (PSSC), and VMD team. The flow process of update vendor profiles can be seen in Figure 5 . The process of update vendor profiles begins with the information that sent by vendor via e-mail. The information can be sent to one parties between DIM or PSC. Information that received the information directly from vendor, then the information has to forwarded first to the related procurement. Data that has been confirmed by the Procurement then will be sent to the PSSC.

PSSC will review the information by checking the validity of vendor e-mail and request an approval to the relevant parties. The data that has been approved will be inputted to the VMDM system. Furthermore, the data that has been input to VMDM will become a request that will verified again by VMD team. The step-process for create and change data is different.

For create data, the request will go to the step of business approver. In business approver, the person in charge will be checking the completeness and validity of document also validity of PSSC who did the request. Next, VMD analyst will recheck the completeness of supporting document and validity of data. The request that has been approved by VMD analyst will go to the step of VMD approver. VMD approver also doing the same process like VMD analyst, and give an approval if the data is compliance. If the request has been fully approved, then the data will be updated on VMDM and SAP. Otherwise, if the request is rejected, then the process will go back to PSSC for re-complete the data. For change data, the step process is similar to create data. But the request on VMDM system will be verified only by two parties that is VMD Analyst and VMD approver. 


\subsection{Problem identification and data collection}

DIM Procurement wants the vendor profiles on system is always up to date. DIM also expected a fast and transparent update process. The result of problem identification shows, the process of delivery information using e-mail is vulnerable to some problems. Several problems that usually occurs such as the mail box is full, information of update vendor data is stacked with other e-mail, e-mail is not well received, and invalid of email address.

DIM received 70 e-mail to 200 e-mail $d^{-1}$ on average, even on specific day DIM can received 300 e-mail $d^{-1}$. The high number of receiving e-mails resulted the information of update vendor profiles is stacked. This also causes DIM did not immediately know when there is an information of vendor profiles that should be updated on system. The update process can be delayed and cause the data on system is not up to date.

The user who uses the data sometimes is not aware of any changes to vendor profiles. It is affected by several things, one of them that is not entire vendor will notify the changes to the user. The update process is only known by some parties, so this cause the user is not aware of any changes of vendor profiles. The update process is take several days until the data can be updated on system. The long processing time and not transparent process could cause discrepancies in data that used by user. The frequency of update process from November 2017 until January 2018 is shown in Figure 4.

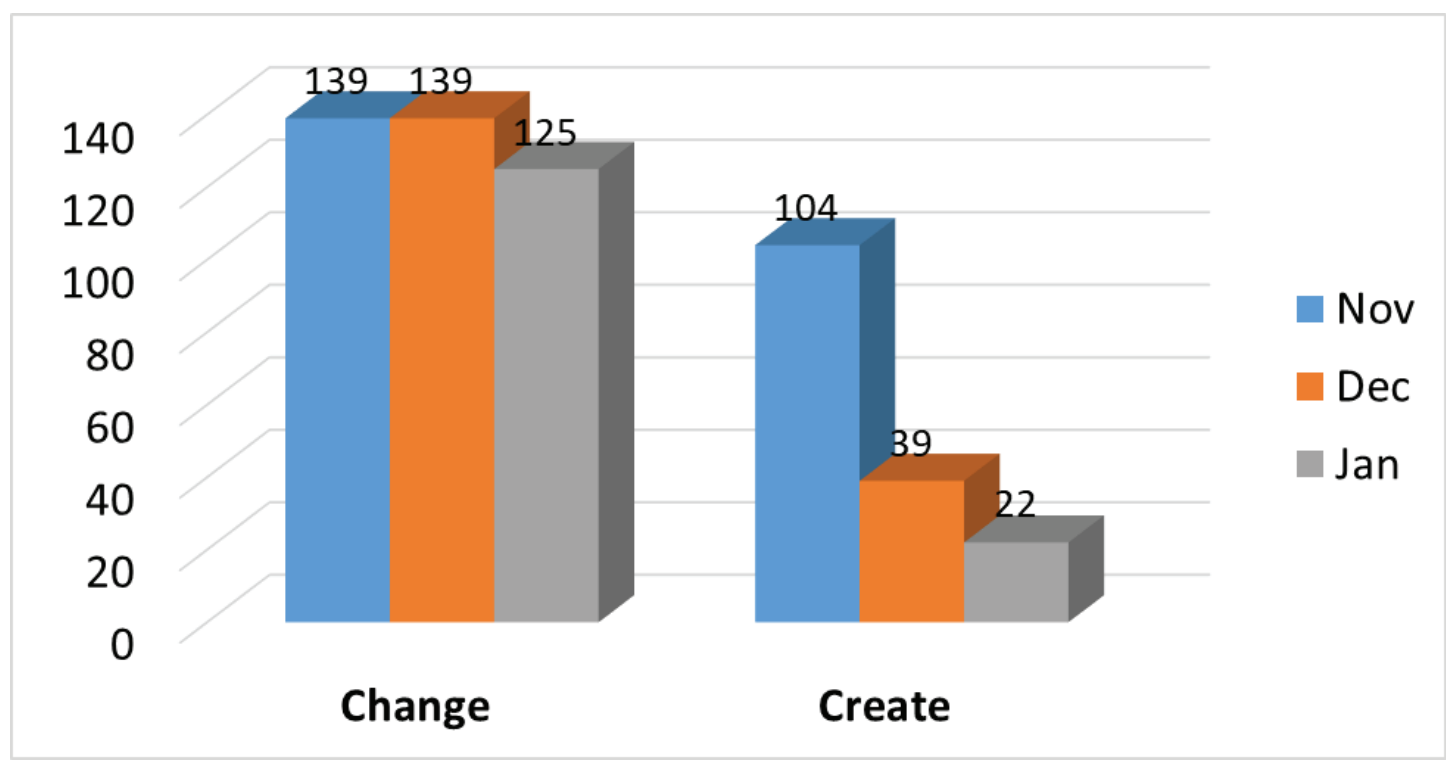

Figure 4: Frequency of update process. 


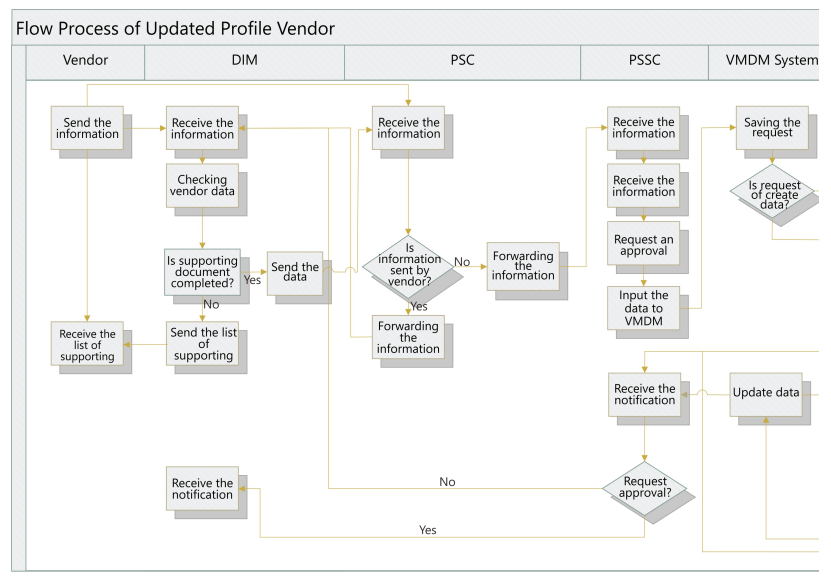

Figure 5: Flow process of update vendor profiles.

The graph in Figure 4 shows the most frequent process of update data is change data. It also provable by 135 requests of change data month ${ }^{-1}$ on average which is equivalent to $71 \%$ of the whole update process. These data indicate the high frequency of Vendor to change their profiles. Based on all types of profile data, there are six types of data that most frequent changed. Bank account is the most frequent changed data. Other data also frequently changes i.e. e-mail address, manager and owner, term of payment, address, and contact number. The processing time of create and change data is different accordance to the step-process undertaken. The process time of create data is shown in Table 2

TABLE 2: Process time of create data.

\begin{tabular}{l|c|c|c|c|c|c|}
\hline Step-process & 1 & 2 & 3 & 4 & 5 & 6 \\
\hline & DIM & PSC & PSSC & $\begin{array}{c}\text { Business } \\
\text { Approver }\end{array}$ & VMD Analyst & $\begin{array}{c}\text { VMD } \\
\text { Approver }\end{array}$ \\
\hline Average & $48 \mathrm{~h}$ to $72 \mathrm{~h}$ & $15 \mathrm{~min}$ & $6 \mathrm{~h}$ & $47.06 \mathrm{~h}$ & $55.84 \mathrm{~h}$ & $19.69 \mathrm{~h}$ \\
\hline Total & \multicolumn{4}{|c|}{$188.59 \mathrm{~h}(8 \mathrm{~d})$} &
\end{tabular}

Based on the Table 2, the longest process time of create data is occurred in the step-process at DIM, Business Approver, and VMD analyst. The length of process time at DIM is affected the number of data that need to be provided by vendor. DIM also need to checking the information and Vendor often do not complete the data correctly. This thing also takes time to re-complete the data from vendor. The number of e-mail that received by DIM is quite a lot, so it's not possible to DIM can notice the update information from Vendor quickly.

The long processing time that occurred at business approver is affected by incomplete supporting document that attached. Not all procurement knows the document that should be provided in update process. This resulted in the data inputted on VMDM 
system often incomplete. The incomplete data will be asked to the vendor again and the completion take up to days.

VMD analyst process is more focus on checking the validity of data and document. The long processing time at VMD analyst is affected by the number of data that have to be checked is quite a lot. Wrong or ambiguous data also require reconfirmation to the vendor or procurement. In addition, sometimes the information that received in this process remains incomplete. Vendor data should have been completed in the step of business approver. However, in some the data that received is still incomplete. The process of checking the data at this step is already takes time. Moreover, with waiting the completion of vendor data and document cause the process of VMD analyst delayed and takes longer time.

VMD analyst does not have a role in contacting the vendor. VMD analyst will inform the required data to the PSSC, and then of the PSSC will contact the procurement and procurement will contact the vendor. This problem cause the process of updating data is longer and takes more time. The process time of change data is shown in Table 3.

TABLE 3: Process time of change data.

\begin{tabular}{|l|c|c|c|c|}
\hline $1 \mathrm{DIM}$ & $2 \mathrm{PSC}$ & $3 \mathrm{PSSC}$ & $4 \mathrm{VMD}$ Analyst & $5 \mathrm{VMD}$ Approver \\
\hline $7 \mathrm{~h}$ & $15 \mathrm{~min}$ & $6 \mathrm{~h}$ & $28.56 \mathrm{~h}$ & $19.69 \mathrm{~h}$ \\
\hline Total & \multicolumn{2}{|c|}{$61.5 \mathrm{~h} \mathrm{(3 \textrm {d } )}$} \\
\hline
\end{tabular}

Table 3 showed the longest processing time of change data is occurred in the stepprocess at VMD analyst and VMD approver. The processing time at DIM also long enough that is $7 \mathrm{~h}$ on average. Vendor who updates their profile are often unaware of the supporting document that required to be attached. DIM have to send back the list of supporting documents that must be attached by vendor. This causes waiting process for vendor to complete the data. This problem also causes back and forth communication that longer the update process. Much better if vendors already know the list of documents they need to provide at the beginning of the process, then can reducing the waiting process and faster the process.

The long processing time at VMD analyst is affected by the waiting process of completing data from vendor, reconfirmation to vendor or procurement, and request an approval that has not been attached. On change process, PSSC needs to attach the approval of the request from the relevant parties. However, sometimes the request has not been approved so it takes time for VMD Analyst to request and waiting for the approval again. 
The longest processing time of change data is occurred in VMD approver. It affected by the special policy that often occurred in the process of change data. This cause the approval from VMD approver cannot be given, and delayed the update process.

The average processing time of create data is $8 \mathrm{~d}$, and change data is $3 \mathrm{~d}$. Supply planning is one of the user that uses vendor profiles for purchase order process. Purchase order $(\mathrm{PO})$ is the process of ordering material which regularly done every single week. The PO process uses e-mail address on SAP system to send the ordered material to the vendor. The fastest PO can be done within $7 \mathrm{~d}$ after bidding process is complete. The long processing time of update data cause the data is not yet available in the system. This may cause delayed delivery of PO and cause other problems of the process in PT. $X$.

Accounting is one of DIM user that uses vendor profiles for payment process. Accounting will be matching the bank account that listed between vendor's invoice and data on SAP system. Sometimes the bank account is not match, so vendor have to updates their bank account on PT. X system. Therefore, the availability and the most updated of vendor data in the system has an important role to support the critical process in PT. X.

The complexity that occurs in the process of Vendor profile data management causes some problems occur. Some problems that have occurred on the update process were as follows.

1. Vendor data is not transferred to SAP

This caused by the error logic that inputted on system. The user that simply does not know about data changes could use the invalid data which actually no longer valid.

2. Vendor doesn't inform the changes data to procurement In this case, vendor who wants to change their profiles inform the changes to accounting and not to procurement. Procurement have to contact the vendor again and waiting for vendor confirmation and cause the process longer.

3. Outsiders make changes to data

Someone ever pretended as vendor and send the information of profile changes to DIM by e-mail. The process by e-mail is a common way to deliver the information, but it also no restriction to outsiders that can send the information of data changes to DIM. Security in the process of update data is certainly important to keep the information data from vendor can be trusted.

4. DIM forget to process the data 
In the process of change data, vendor usually only send their information to one person of DIM. So, if the person forgot to process the data then the data on system will also not be updated. In this case, some people of DIM don't know if the e-mail address of vendor has been change since the data that provided on system also has not changed. This cause the vendor failed to receive such information on tax declaration.

5. Process of vendor data review is not effective

Vendor data review is a regular activity from procurement in every year to ensure that the current info in the system is correct. In this process, DIM will ask the confirmation from vendor about their current e-mail address and bank account. Based on process of vendor data review 2018, from 118 vendors that has been asked, only 55 vendors replied the confirmation before the specific due date. About 63 vendors must be reminded again by sending e-mail manually one by one. Other problem that occurs in this process, such as 19 vendors does not complete and understand the data requested, 14 vendors don't reply the confirmation, two vendors hesitate with the validity of requestor, two e-mail is going to spam, and double confirmation by two parties from procurement. Each vendor requires about $3 \mathrm{~d}$ and $15 \mathrm{~h}$ on average to reply the confirmation completely.

6. DIM does not know if other affiliate makes changes to Vendor profiles

The majority of vendor that used by DIM PT. $X$ is global vendor. Global vendor is defined as the vendor that also used by all affiliates of PT. X. So, if the vendor profiles are changed then it will have affected the whole affiliate. Each affiliates do not receive the notification if there is changes in vendor profiles.

\subsection{Problem cause analysis}

Based on the results of the problem identification earlier, there are four main problems in process of vendor profile data management. The first main problems are vendor data review process is not running effectively. Second, the process of delivering information is not effective. Third, the long processing time of update profile data. Fourth, the process is not transparent. The root causes analysis was conducted using five whys analysis as shown in Table 4.

The five whys analysis in Table 4 starts with the main problems that occurs in the process of vendor profile data management. It was determined vendor data review process is not running effectively because of six causes. The process of delivering 
information is not effective have seven causes. The long processing time of update data was also determined because of nine causes. The last problem that is not transparent process was also determined because of eight causes. There is some problem that actually have the same causes. So by fixing the causes, then it can fix some problem at once. Overall, there are 19 root causes that occurs in the process of vendor profile data management.

\subsection{The proposed improvement solutions}

The solutions are expected can improve the process of vendor profile data management. The proposed solutions can be seen in Table 4 . There are 10 proposed solutions that given to fix the root causes identified, the proposed solution is as follows.

1. Confirmation data is using the official portal of DIM and can be accessed by internal PT. X.

All information related to the data confirmation is using one official portal DIM. Through this portal, each process is more transparent and can be seen easily for all DIM. This solution is expected to eliminate doubt from Vendor to answer the confirmation data, and prevent unreceivable information that happens because of mail problems. Total time that wasted by the problem which actually can be overcome by this solution is $2880 \mathrm{~h}$.

2. A system that requires vendors to fill data with complete and given a description of each type data

In this solution, vendor will always fill in the required data and also understand any data requested. This solution is expected to eliminate the back and forth process and faster the process. This solution also expected to improve the operations of the data vendor process review. Based on 19 cases of problems that occur, the results of this solution is expected to reduce as much time as follows. 19 cases $x$ $34.2 \mathrm{~h}=649.8 \mathrm{~h}$

If the first and second is applied then the result on these solution is expected to reduce the average of vendor to replied the confirmation with completely which was originally $3 \mathrm{~d} 15 \mathrm{~h}$ to $2 \mathrm{~d} 9 \mathrm{~h}$.

3. Automatic reminder

Each vendor is given a time limit for data confirmation, and the vendor who passed the time limit will be reminded automatically. This solution requires the design of 
new system with automatic reminder. This solution is expected could save more time and effort than to send reminder manually one by one, so DIM can do other tasks that has more value added.

4. Send and receive information of update data using one portal system

Any process of delivering information related to data updates will only go through one official system portal from DIM procurement. This proposal automatically impacts the information flow of vendors that are no longer divided between DIM and PSC. The whole process will be directly accepted by the portal procurement, and the role of PSC is no longer needed. Each parties that involved in the update process will be connected within this system. This solution is expected to make the process becomes clearer and information of update data more organized.

5. Self-update by vendor

So far vendor has only a role in delivering their information about data updates. Incomplete and inappropriate data becomes a common problem. In this solution, vendors are given a direct role in managing their profile data so they can also view any data stored on the system. Therefore, it is expected to eliminating the waiting process for incomplete and confirmation of inappropriate data. The changes from vendor can also be known by all procurement so the process is more transparent.

\section{Automatic notification}

All users will receive notification of each update process. So they can know each process from vendor thereby preventing the use of invalid data. Although the data has not been updated in the system, the users will aware if there is a data changes.

\section{Personal account}

Each vendor must have an account for managing their data and the only verified Vendors that can access the system to update data. This solution is expected to increase the security of update process and to prevent the occurrence of outsiders who pretended as vendor to update data.

8. The list of supporting documents required are listed automatically on system In this solution, the required list of supporting documents is listed automatically in each category of profile data. This solution is expected so that vendor can understand what documents need to be provided from beginning and of course eliminate of sending the supporting document manually.

9. The list of supporting documents in the form of posters 
The solution of list supporting document earlier takes time for the design, development and the implementation. Therefore, a temporary solution is given and can be applied that as a visual representation of posters that informs the list of supporting documents required for data updates. This solution aims to temporarily help while waiting for the implementation of previous solution. This solution is expected to eliminating back and forth process.

10. Provides a guide about the process of update vendor profile to all vendors Socializing the guidance of updating vendor profile data is required so that vendors can clearly understand the flow process. This solution aims to standardize the process performed by all vendors so the information from Vendor can be delivered to the right party and the process is done quickly.

Digitalization is the overall solution that can improve the process of vendor profile data management. About eight out of 10 proposed solutions that have been outlined can be realize by digital transformation. Digitalization is done by changing the process of delivering information which initially using e-mail, now using an online portal system called DIM Vendor Profile Management. DIM Vendor Profile Management system will be connecting each parties who involved in the process and improve the process to becoming more effective, efficient, and transparent.

TABLE 4: Results of root cause analysis.

\begin{tabular}{|c|c|c|c|c|c|}
\hline Problem & Why 1 & Why 2 & Why 3 & Why 4 & Why 5 \\
\hline \multirow[t]{5}{*}{$\begin{array}{l}\text { Vendor Data } \\
\text { Review Not } \\
\text { Running } \\
\text { Effectively }\end{array}$} & $\begin{array}{l}\text { The process of } \\
\text { data recap } \\
\text { does not finish } \\
\text { within } 30 \mathrm{~d}\end{array}$ & $\begin{array}{l}\text { The process of } \\
\text { delivering } \\
\text { information is } \\
\text { ineffective }\end{array}$ & $\begin{array}{l}63 \text { vendors } \\
\text { must be } \\
\text { reminded again } \\
\text { by sending } \\
\text { e-mail manually } \\
\text { one by one }\end{array}$ & $\begin{array}{l}\text { E-mail does not } \\
\text { have automatic } \\
\text { reminder } \\
\text { features }\end{array}$ & $\begin{array}{l}\text { E-mail does not } \\
\text { have automatic } \\
\text { reminder } \\
\text { features }\end{array}$ \\
\hline & & & $\begin{array}{l}16 \text { vendors } \\
\text { must be } \\
\text { reminded again } \\
\text { by manager }\end{array}$ & $\begin{array}{l}\text { Vendor does } \\
\text { not respond the } \\
\text { requestor }\end{array}$ & $\begin{array}{l}\text { Vendors never } \\
\text { interact with the } \\
\text { requestor }\end{array}$ \\
\hline & & $\begin{array}{l}\text { Vendor does } \\
\text { not reply to } \\
\text { e-mail }\end{array}$ & $\begin{array}{l}\text { Vendors } \\
\text { hesitate with } \\
\text { the validity of } \\
\text { the requestor }\end{array}$ & $\begin{array}{l}\text { Vendor does } \\
\text { not recognize } \\
\text { the requestor }\end{array}$ & \\
\hline & & & $\begin{array}{l}\text { Vendor does } \\
\text { not received } \\
\text { the e-mail }\end{array}$ & $\begin{array}{l}\text { Problems with } \\
\text { e-mail }\end{array}$ & $\begin{array}{l}\text { Problems with } \\
\text { e-mail }\end{array}$ \\
\hline & & $\begin{array}{l}\text { Back and forth } \\
\text { communication }\end{array}$ & $\begin{array}{l}13 \text { vendors } \\
\text { does not } \\
\text { complete the } \\
\text { data }\end{array}$ & $\begin{array}{l}\text { Vendors ignore } \\
\text { the data } \\
\text { request }\end{array}$ & $\begin{array}{l}\text { Vendors are not } \\
\text { paying attention } \\
\text { to the } \\
\text { requested data }\end{array}$ \\
\hline
\end{tabular}




\begin{tabular}{|c|c|c|c|c|c|}
\hline \multirow[t]{3}{*}{ Problem } & \multirow[t]{2}{*}{ Why 1} & \multirow[t]{2}{*}{ Why 2} & \multirow{2}{*}{$\begin{array}{l}\text { Why } 3 \\
\text { six vendors } \\
\text { does not } \\
\text { understand the } \\
\text { data requested }\end{array}$} & \multirow{2}{*}{$\begin{array}{l}\text { Why } 4 \\
\text { No description } \\
\text { of each data }\end{array}$} & \multirow{2}{*}{$\begin{array}{l}\text { Why } 5 \\
\text { No description } \\
\text { of each data }\end{array}$} \\
\hline & & & & & \\
\hline & $\begin{array}{l}\text { Double process } \\
\text { of confirmation }\end{array}$ & $\begin{array}{l}\text { Each party not } \\
\text { knowing the } \\
\text { process }\end{array}$ & $\begin{array}{l}\text { Unclear } \\
\text { communication }\end{array}$ & $\begin{array}{l}\text { The process is } \\
\text { not transparent }\end{array}$ & $\begin{array}{l}\text { The process is } \\
\text { not transparent }\end{array}$ \\
\hline \multirow[t]{8}{*}{$\begin{array}{l}\text { The Process of } \\
\text { Delivering } \\
\text { Information Not } \\
\text { Effective }\end{array}$} & $\begin{array}{l}\text { E-mail } \\
\text { vulnerable to } \\
\text { some problems }\end{array}$ & $\begin{array}{l}\text { DIM did not } \\
\text { notice if there is } \\
\text { an e- mail of } \\
\text { update data }\end{array}$ & $\begin{array}{l}\text { Information of } \\
\text { update data is } \\
\text { stacked of } \\
\text { other e-mail }\end{array}$ & $\begin{array}{l}\text { Information via } \\
\text { e-mail mixed } \\
\text { with other } \\
\text { information }\end{array}$ & $\begin{array}{l}\text { Information via } \\
\text { e-mail mixed } \\
\text { with other } \\
\text { information }\end{array}$ \\
\hline & & & $\begin{array}{l}\text { E-mail is going } \\
\text { to spam }\end{array}$ & $\begin{array}{l}\text { Problem with } \\
\text { e-mail }\end{array}$ & $\begin{array}{l}\text { Problem with } \\
\text { e-mail }\end{array}$ \\
\hline & & $\begin{array}{l}\text { The e-mail is } \\
\text { not received }\end{array}$ & $\begin{array}{l}\text { Invalid e-mail } \\
\text { address }\end{array}$ & $\begin{array}{l}\text { Wrong input of } \\
\text { e-mail address }\end{array}$ & Human error \\
\hline & & Manual process & $\begin{array}{l}\text { DIM have to } \\
\text { send the list of } \\
\text { supporting } \\
\text { document one } \\
\text { by one }\end{array}$ & $\begin{array}{l}\text { Vendors do not } \\
\text { understand the } \\
\text { supporting } \\
\text { documents }\end{array}$ & $\begin{array}{l}\text { There is no } \\
\text { description of } \\
\text { supporting } \\
\text { documents that } \\
\text { need to be } \\
\text { provided }\end{array}$ \\
\hline & $\begin{array}{l}\text { Back and forth } \\
\text { communication }\end{array}$ & $\begin{array}{l}\text { Vendors do not } \\
\text { understand the } \\
\text { supporting } \\
\text { documents }\end{array}$ & $\begin{array}{l}\text { There is no } \\
\text { description of } \\
\text { supporting } \\
\text { documents that } \\
\text { need to be } \\
\text { provided }\end{array}$ & $\begin{array}{l}\text { There is no } \\
\text { description of } \\
\text { supporting } \\
\text { documents that } \\
\text { need to be } \\
\text { provided }\end{array}$ & \\
\hline & & $\begin{array}{l}\text { Vendors does } \\
\text { not complete } \\
\text { the data }\end{array}$ & $\begin{array}{l}\text { Vendors ignore } \\
\text { the data } \\
\text { request }\end{array}$ & $\begin{array}{l}\text { Vendors are not } \\
\text { paying attention } \\
\text { to the } \\
\text { requested data }\end{array}$ & $\begin{array}{l}\text { Vendors are not } \\
\text { paying attention } \\
\text { to the } \\
\text { requested data }\end{array}$ \\
\hline & & $\begin{array}{l}\text { Vendors do not } \\
\text { understand the } \\
\text { requested data } \\
\text { and documents }\end{array}$ & $\begin{array}{l}\text { Different } \\
\text { understanding } \\
\text { of data and } \\
\text { documents }\end{array}$ & $\begin{array}{l}\text { No description } \\
\text { of each data }\end{array}$ & $\begin{array}{l}\text { No description } \\
\text { of each data }\end{array}$ \\
\hline & $\begin{array}{l}\text { Outsiders make } \\
\text { changes to data }\end{array}$ & $\begin{array}{l}\text { The process of } \\
\text { deliver } \\
\text { information only } \\
\text { by e-mail }\end{array}$ & $\begin{array}{l}\text { E-mail does not } \\
\text { restrict certain } \\
\text { people }\end{array}$ & $\begin{array}{l}\text { E-mail does not } \\
\text { restrict certain } \\
\text { people }\end{array}$ & $\begin{array}{l}\text { E-mail does not } \\
\text { restrict certain } \\
\text { people }\end{array}$ \\
\hline \multirow[t]{2}{*}{$\begin{array}{l}\text { The Long } \\
\text { Processing } \\
\text { Time of Update } \\
\text { Profile Data }\end{array}$} & $\begin{array}{l}\text { The average } \\
\text { process of } \\
\text { create data } \\
\text { takes up to } 8 \\
\text { working days } \\
\text { with the longest } \\
\text { processing time } \\
\text { of } 17 \mathrm{~d}\end{array}$ & $\begin{array}{l}\text { Process time of } \\
\text { business } \\
\text { approver is } 47 \mathrm{~h} \\
\text { on average }\end{array}$ & $\begin{array}{l}\text { Vendors do not } \\
\text { attach } \\
\text { supporting } \\
\text { documents as } \\
\text { required }\end{array}$ & $\begin{array}{l}\text { Vendors are not } \\
\text { paying attention } \\
\text { to the } \\
\text { requested data }\end{array}$ & $\begin{array}{l}\text { Vendors are not } \\
\text { paying attention } \\
\text { to the } \\
\text { requested data }\end{array}$ \\
\hline & & & & $\begin{array}{l}\text { Vendors do not } \\
\text { understand the } \\
\text { supporting } \\
\text { documents }\end{array}$ & $\begin{array}{l}\text { There is no } \\
\text { description of } \\
\text { supporting } \\
\text { documents that } \\
\text { need to be } \\
\text { provided }\end{array}$ \\
\hline
\end{tabular}




\begin{tabular}{|c|c|c|c|c|c|}
\hline \multirow[t]{11}{*}{ Problem } & Why 1 & Why 2 & Why 3 & Why 4 & Why 5 \\
\hline & & $\begin{array}{l}\text { Process time of } \\
\text { VMD analyst } \\
\text { is } 55 \mathrm{~h} \text { on } \\
\text { average }\end{array}$ & $\begin{array}{l}\text { VMD analyst } \\
\text { waiting for data } \\
\text { completion }\end{array}$ & $\begin{array}{l}\text { Data and } \\
\text { documents are } \\
\text { incomplete }\end{array}$ & $\begin{array}{l}\text { The data not } \\
\text { yet completed } \\
\text { on business } \\
\text { approver }\end{array}$ \\
\hline & & & & $\begin{array}{l}\text { VMD analyst } \\
\text { does not have a } \\
\text { role in } \\
\text { contacting the } \\
\text { Vendor }\end{array}$ & $\begin{array}{l}\text { Procurement } \\
\text { that has the role } \\
\text { for contacting } \\
\text { vendor }\end{array}$ \\
\hline & & & $\begin{array}{l}\text { Waiting for } \\
\text { Vendor } \\
\text { confirmation }\end{array}$ & $\begin{array}{l}\text { Wrong or } \\
\text { ambiguous data }\end{array}$ & Wrong data \\
\hline & & & & $\begin{array}{l}\text { Invalid vendor } \\
\text { document }\end{array}$ & \\
\hline & $\begin{array}{l}24 \text { process of } \\
\text { change data } \\
\text { takes more than } \\
3 \mathrm{~d} \text {, with the } \\
\text { longest time } \\
\text { being } 14 \mathrm{~d}\end{array}$ & $\begin{array}{l}\text { Process of VMD } \\
\text { analyst is } \\
\text { obstructed }\end{array}$ & $\begin{array}{l}\text { Waiting for } \\
\text { Vendor or } \\
\text { Procurement } \\
\text { confirmation }\end{array}$ & & \\
\hline & & & & $\begin{array}{l}\text { Wrong or } \\
\text { ambiguous data }\end{array}$ & \\
\hline & & & $\begin{array}{l}\text { Waiting for } \\
\text { approval } \\
\text { process }\end{array}$ & $\begin{array}{l}\text { The person did } \\
\text { not notice if } \\
\text { there is an } \\
\text { e-mail of } \\
\text { updating data }\end{array}$ & $\begin{array}{l}\text { Information of } \\
\text { update data is } \\
\text { stacked of } \\
\text { other e-mail }\end{array}$ \\
\hline & & & $\begin{array}{l}\text { Vendors does } \\
\text { not complete } \\
\text { the data }\end{array}$ & $\begin{array}{l}\text { Vendors do not } \\
\text { attach } \\
\text { supporting } \\
\text { documents as } \\
\text { required }\end{array}$ & $\begin{array}{l}\text { Vendors are not } \\
\text { paying attention } \\
\text { to the } \\
\text { requested data }\end{array}$ \\
\hline & & & & & $\begin{array}{l}\text { vendors do not } \\
\text { understand the } \\
\text { supporting } \\
\text { documents }\end{array}$ \\
\hline & & $\begin{array}{l}\text { The average } \\
\text { process time of } \\
\text { VMD approver } \\
\text { process is } \\
28.56 \mathrm{~h}\end{array}$ & $\begin{array}{l}\text { The approval } \\
\text { process is } \\
\text { delayed }\end{array}$ & $\begin{array}{l}\text { Special policy } \\
\text { that affecting } \\
\text { the process of } \\
\text { approval }\end{array}$ & $\begin{array}{l}\text { Special policy } \\
\text { that affecting } \\
\text { the process of } \\
\text { approval }\end{array}$ \\
\hline \multirow[t]{3}{*}{$\begin{array}{l}\text { The Process } \\
\text { Not Transparent }\end{array}$} & $\begin{array}{l}\text { User DIM is not } \\
\text { aware of any } \\
\text { changes to } \\
\text { vendor profile } \\
\text { data }\end{array}$ & $\begin{array}{l}\text { Accounting } \\
\text { does not } \\
\text { receive the } \\
\text { information }\end{array}$ & $\begin{array}{l}\text { Information of } \\
\text { update data } \\
\text { only received } \\
\text { by Procurement }\end{array}$ & $\begin{array}{l}\text { Information of } \\
\text { update data } \\
\text { only received } \\
\text { by Procurement }\end{array}$ & $\begin{array}{l}\text { Information of } \\
\text { update data } \\
\text { only received } \\
\text { by Procurement }\end{array}$ \\
\hline & & $\begin{array}{l}\text { Supply Planning } \\
\text { is sometimes } \\
\text { unaware of any } \\
\text { change of } \\
\text { profile data }\end{array}$ & $\begin{array}{l}\text { Does not } \\
\text { receive the } \\
\text { information } \\
\text { from Vendor }\end{array}$ & $\begin{array}{l}\text { Information of } \\
\text { update data } \\
\text { only received } \\
\text { by Procurement }\end{array}$ & \\
\hline & & & & $\begin{array}{l}\text { Do not receive } \\
\text { E-mail from } \\
\text { vendor }\end{array}$ & $\begin{array}{l}\text { Problem with } \\
\text { e-mail }\end{array}$ \\
\hline
\end{tabular}




\begin{tabular}{|c|c|c|c|c|c|}
\hline Problem & Why 1 & Why 2 & Why 3 & Why 4 & Why 5 \\
\hline & & & $\begin{array}{l}\text { Does not notice } \\
\text { the e-mail } \\
\text { about update } \\
\text { data }\end{array}$ & $\begin{array}{l}\text { The information } \\
\text { is stacked with } \\
\text { other e-mail }\end{array}$ & $\begin{array}{l}\text { Information via } \\
\text { e-mail mixed } \\
\text { with other } \\
\text { information }\end{array}$ \\
\hline & & & $\begin{array}{l}\text { SAP is not } \\
\text { downloaded } \\
\text { regularly }\end{array}$ & $\begin{array}{l}\text { Planning } \\
\text { usually get } \\
\text { information } \\
\text { from vendors } \\
\text { via e- mail }\end{array}$ & $\begin{array}{l}\text { Planning } \\
\text { usually get } \\
\text { information } \\
\text { from vendors } \\
\text { via e-mail }\end{array}$ \\
\hline & & $\begin{array}{l}\text { The data in SAP } \\
\text { has not } \\
\text { changed }\end{array}$ & $\begin{array}{l}\text { The vendor } \\
\text { data is not } \\
\text { transferred to } \\
\text { SAP }\end{array}$ & $\begin{array}{l}\text { Logic error on } \\
\text { system }\end{array}$ & $\begin{array}{l}\text { Logic error on } \\
\text { system }\end{array}$ \\
\hline & $\begin{array}{l}\text { Vendor doesn't } \\
\text { inform the } \\
\text { changes data to } \\
\text { procurement }\end{array}$ & $\begin{array}{l}\text { Vendors inform } \\
\text { the data } \\
\text { changes to } \\
\text { parties relating } \\
\text { to the process }\end{array}$ & $\begin{array}{l}\text { Vendors do not } \\
\text { understand } \\
\text { system data } \\
\text { update process }\end{array}$ & $\begin{array}{l}\text { There is no } \\
\text { guidance } \\
\text { regarding the } \\
\text { system data } \\
\text { update process }\end{array}$ & $\begin{array}{l}\text { There is no } \\
\text { guidance } \\
\text { regarding the } \\
\text { system data } \\
\text { update process }\end{array}$ \\
\hline & $\begin{array}{l}\text { Send the data } \\
\text { information to } \\
\text { e- mail vendors } \\
\text { that have been } \\
\text { inactive }\end{array}$ & $\begin{array}{l}\text { Users do not } \\
\text { know the e-mail } \\
\text { is not active }\end{array}$ & $\begin{array}{l}\text { E-mail data on } \\
\text { the system has } \\
\text { not been } \\
\text { updated }\end{array}$ & $\begin{array}{l}\text { Forget to } \\
\text { process the } \\
\text { data }\end{array}$ & Human error \\
\hline & & & $\begin{array}{l}\text { Not all DIM } \\
\text { parties know } \\
\text { the data update } \\
\text { information } \\
\text { from the vendor }\end{array}$ & $\begin{array}{l}\text { Vendor only } \\
\text { send their } \\
\text { information to } \\
\text { one person of } \\
\text { DIM }\end{array}$ & $\begin{array}{l}\text { Vendor only } \\
\text { send their } \\
\text { information to } \\
\text { one person of } \\
\text { DIM }\end{array}$ \\
\hline
\end{tabular}

\subsection{Concept of DIM vendor profile management}

DIM Vendor Profile Management is a system that provides access directly to Vendors, procurement, PSSC and DIM user for connected in one system. DIM Vendor Profile Management is one of the functions owned on a platform called DIM Vendor Management. Platform DIM Vendor Management can be accessed using a web browser that connected to internet network.

In this portal, vendor is given the access directly to manage and update their profile data. Procurement and PSSC can also receive information directly through the system. In addition, approval and correction data to vendor can be done through the system. DIM user also be notified whether there is a vendor that updates their data. VMD team is not connected in this portal, because they have their own scope that is VMDM system. So this system is expected to have a function as a wall that mediates the information between vendors with procurement, the procurement and PSSC, and also to inform the updates process to the user DIM. The existence of this system directly change all the way current update process. 


\subsubsection{Flow process of the proposed improvement solution}

At the beginning, each user must register an account by entering their personal data to access the system. Personal data that need to be filled i.e. e-mail address, full name, password, type of user, and job position. Type of user will be differentiated the access between vendor and internal party of PT. X. Responsible procurement will be verifying the account that has been registered. User who has been verified can automatically access the system by log in to the system. The flow process of proposed improvement solution is given in Figure 6.

The flow process begins with the updates by vendor. Each updates by vendor will not directly update the data on system. However, the update become a request that will received by DIM. Each updates from vendor then the user will be notified. DIM has three options that can be performed for the request. The first option is "approve" which indicates the request is accepted and forwarded to PSSC. The second option that is "reject to correction", which indicates the request is rejected and the request will return to vendor for correction. The third option that is "reject total", which indicates the request was totally denied and vendor will be received the notification.

The request that has been approved by the procurement will automatically forwarded to PSSC. PSSC will choose "approve" option, which indicated the data is being processed on VMDM system. PSSC will download the data from DIM system, request an approval to the related parties if needed, and input the data to VMDM system. Furthermore, the process will be the same as the flow process of initial conditions. VMD team will checking the completeness and validity of data. If the request is rejected, as usual PSSC will receive notification from VMD team via e-mail. Next, PSSC will notify the information to vendor through DIM system. There are two options that can be selected for rejection same as the option that Procurement have, that is "reject to correction" and "reject final". Meanwhile, if the request that was approved then the data in VMDM and SAP system will automatically be updated.

PSSC will receive the notification regarding the approval of request from VMD team via e-mail. PSSC will inform the approval through DIM system by choosing options "completed". After that vendors, procurement, and DIM user will receive notifications about the completion of update request. Finally, the updates by vendor which initially still a request on DIM system, will automatically updates the data on system. 


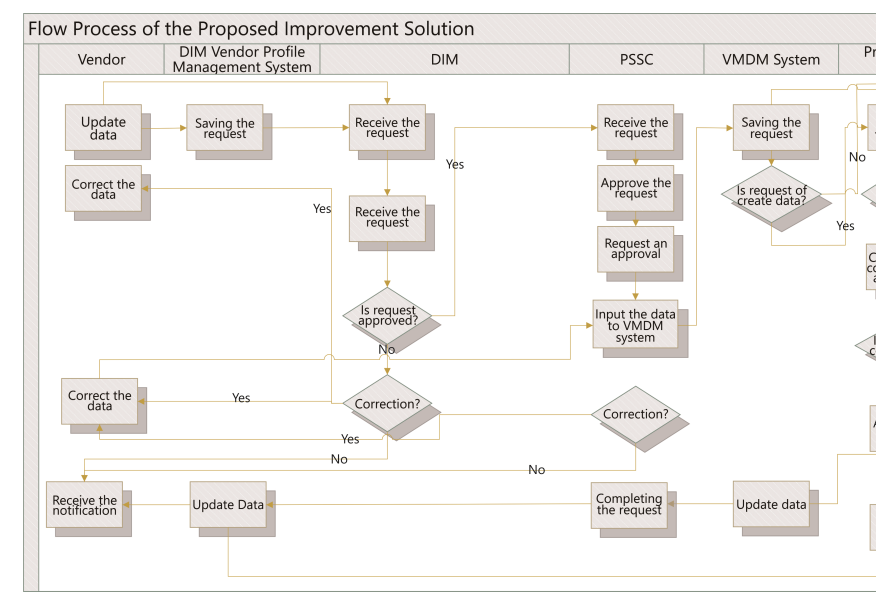

Figure 6: Flow process of the proposed improvement.

\section{Conclusion}

The first objective of this research is to find out the root causes in process of vendor profile data management. The result shows there are 19 root causes occur in the process. Some of the main problem have the same root cause. So by resolving the root cause, then it can fix several problems at once. There are 10 proposed solutions given in this research. As many as eight out of 10 solutions can be realized through digitalization process. Digitalization using a portal system called DIM Vendor profile management that will connect each party who involve of updating process. This solution is expected will improve the process for becoming more effective, efficient, and transparent. Vendor data review process is also expected can be reduced to from $3 \mathrm{~d} 15 \mathrm{~h}$ to $2 \mathrm{~d} 9 \mathrm{~h}$. Another solution is a poster that informing the list of supporting document and distributed to all vendor. This is a temporary solution that can be applied while waiting for the deployment for digitalization solution. This solution is expected to reduce waiting process also back and forth communication process. Socialization about the process of updating data is the last solution that given in this research. Vendors are clearly notified about the process of updating data. So they could understand and do the process appropriately.

\section{References}

[1] Schmidt R, Möhring M, Härting RC, Reichstein C. Industry 4.0 potentials for creating smart products: empirical research results. business information systems. In: Business Information Systems. Abramowicz W (Eds). Springer, Cham; 2015. pp. 16--27. https://link.springer.com/chapter/10.1007/978-3-319-19027-3_2 
[2] BDC. Industry 4.0: the new industrial revolution. Business Development Bank of Canada, Canada; 2017. pp. 10--12. https://www.bdc.ca/en/about/sme_research/ pages/industry-4-new-industrial-revolution.aspx

[3] Parviainen P, Tihinen M, Kaariainen J, Teppola S. Tackling the digitalization challenge: how to benefit from digitalization in practice. International Journal of Information Systems and Project Management 2017; 5(1):63--77. https://doaj.org/ article/546ce85b31d749e3b117229fd26e0a78

[4] Yukins CR, Schooner SL. Incrementalism: eroding the impediments to a. global public procurement market. Georgetown Journal of International Law 2007; 38:529--576. https://scholarship.law.gwu.edu/faculty_publications/119/

[5] Geissbauer R, Vedso J, Schrauf S. Are you ready for digital revolution? PWC [Online] from https://www.strategyand.pwc.com/media/file/Procurement-4.pdf (2015). [Access on 15 January 2018]

[6] Mahto D, Kumar A. Application of root cause analysis in improvement of product quality and productivity. Journal of Industrial Engineering and Management 2008; 1(2):16--53. http://www.jiem.org/index.php/jiem/article/view/3

[7] Tomic B, Brkic VS. Effective root cause analysis and corrective action process. Journal of Engineering Management and Competitiveness 2011; 1(1/2):16--20. http: //www.tfzr.uns.ac.rs/jemc/files/V1N1-22011-04.pdf

[8] Rooney JJ, Heuvel LNV. Root cause analysis for beginners [Online] from https://www.env.nm.gov/aqb/Proposed_Regs/Part_7_Excess_Emissions/ NMED_Exhibit_18-Root_Cause_Analysis_for_Beginners.pdf (2004). [Accessed on 15 January 2018]

[9] Mourtzis D, Doukas M, Skrepetos T. Knowledge-enriched problem solving methodology for the design phase of manufacturing equipment. Procedia CIRP 2015; 36:95--100. https://www.sciencedirect.com/science/article/pii/S2212827115000050

[10] British Retail Consortium. Understanding root cause analysis [Online] from (2012). [Accessed on 15 January 2018]. https://images.template.net/wp-content/uploads/ 2015/10/17170204/Fishbone-Template-for-Root-Cause-Analysis.pdf

[11] Gano DL. Apollo root cause analysis: a new way of thinking. 3rd Ed. Apollonian Publications, Richland; 2007. pp. 34--40. https://books.google.co.id/books?id= VOqxLAAACAAJ\&dq=Apollo+root+cause+analysis:+a+new+way+of+thinking\&hl= en\&sa=X\&ved=0ahUKEwiwruGnhfHjAhVPeHOKHZmmBMgQ6AEIKjAA 